\title{
Culture-Based Assessment of Microbial Communities in Soil Suppressive to Potato Common Scab
}

Qingxiao Meng, Jingfang Yin, and Noah Rosenzweig, Department of Plant Pathology; David Douches, Department of Crop and Soil Sciences; and Jianjun J. Hao, Department of Plant Pathology, Michigan State University, East Lansing \begin{abstract}
to potato common scab. Plant Dis. 96:712-717.
\end{abstract}
Abstract

Meng, Q. X., Yin, J. F., Rosenzweig, N., Douches, D., and Hao, J. J. 2012. Culture-based assessment of microbial communities in soil suppressive ing in culture with $S$. scabies. The frequency of antagonistic bacteria in SS was higher than common-scab-conducive soil (CS) in all four groups but only pseudomonads and streptomycetes were significantly higher. The population of pathogenic Streptomyces spp. in the rhizosphere of CS was significantly higher than SS. Dilution plating of CS and SS samples showed no clear trends or differences in populations of total fungi, total bacteria, streptomycetes, fluorescent pseudomonads, and bacilli but terminal restriction fragment polymorphism analysis revealed two distinct microbial communities were present in SS and CS.
Potato common scab (PCS) is caused by Streptomyces spp. Since its first report in North America in the late 19th century, the disease has been found worldwide wherever potato is grown. Streptomyces spp. are persistent soil inhabitants that survive saprotrophically in soil for long periods in the absence of hosts. Usually, the disease affects tuber quality by resulting in superficial, raised, or pitted lesions on the periderm $(19,20)$. In some cases, potato yield can be reduced due to severe infection. PCS threatens the $\$ 3.5$ billion potato industry (NASS, 2010) due to lack of effective control methods (9).

Management of PCS is difficult. Scab-resistant cultivars are the ultimate goal but current commercial varieties have only partial resistance or tolerance (35). The only widely used chemical, pentachloronitrobenzene (5), has been withheld in the United States recently by the Environmental Protection Agency (EPA) due to its carcinogenicity and nondegradability in soil (EPA website). Increasing irrigation intensity and lowering soil $\mathrm{pH}$ are partially effective in reducing the disease severity but lower $\mathrm{pH}$ may also result in yield reduction (9). Cultural practices, such as organic soil amendments, green manures, and crop rotation, have been shown to reduce PCS by improving the beneficial soil microbial community $(12,37)$.

Naturally occurring disease-suppressive soils provide a valuable resource for studying beneficial microbial communities (2). A number of soils have been reported as suppressive against plant diseases, including Fusarium wilt (Fusarium oxysporum), damping-off (Pythium spp.), root rot (Rhizoctonia solani), take-all (Gaeumannomuces graminis var. tritici), and PCS (Streptomyces scabies) $(7,10,13,36)$. In the 1950 s, Menzies observed that PCS disease severity was almost zero in a field after many years of potato monoculture in central Washington, and the suppressiveness was biological (24). Decline of common scab with potato mono-

Corresponding author: J. Hao, E-mail: jjhao@msu.edu

Accepted for publication 27 November 2011.

http://dx.doi.org/10.1094/PDIS-05-11-0441

(C) 2012 The American Phytopathological Society culture was also identified in fields at Grand Rapids and Becker, MN $(14,16)$. In these systems, nonpathogenic Streptomyces spp. are believed to play a major role in disease suppressiveness $(15,17)$. Elucidating the mechanisms for suppressiveness may help to improve soil health through manipulating the microbial communities.

In recent years, the authors have observed a decline in PCS in a potato field near the campus of Michigan State University, East Lansing, and decided to evaluate the soil microbial communities implicated in the disease suppressiveness of these fields. Knowing the specific soil profile of suppressive soil may help us to improve soil health by adding various amendments. Various techniques are available to enumerate, identify, and culture microorganisms, such as selective media-based methods (32) and molecular approaches surveying the entire microbial community present in a soil (33). The main objectives of this work were to determine whether the soil was suppressive to PCS, characterize the structure of microbial communities likely contributing to the disease suppressiveness, and culture specific beneficial microorganisms or microbial communities that can be reestablished to control common scab. A preliminary report has been published (23). A related study using pyrosequencing to characterize soil microbial communities will be reported separately (29).

\section{Materials and Methods}

Field history and soil properties. A field (N42 $43.014^{\prime}$, W84 ${ }^{\circ} 27.972^{\prime}$ ) near the campus of Michigan State University in East Lansing has been cultivated with potato consecutively for more than 25 years. This field, designated as the scab-suppressive (SS) field, was used as a scab nursery for potato variety evaluation. Because the disease declined gradually over several years, the varietal test was moved to a new field $\left(\mathrm{N} 42^{\circ} 42.937^{\prime}, \mathrm{W} 84^{\circ} 27.975^{\prime}\right)$ in 2005 , designated as the scab-conducive soil (CS) field, in the same area, separated by a distance of $200 \mathrm{~m}$. This field showed higher disease pressure of PCS according to disease ratings from the past 5 years. Soil samples collected from SS and CS fields were analyzed for physical and chemical properties at the Michigan State University's Soil and Plant Nutrient Laboratories using different methods for each element as recommended for the NorthCentral Region. The soil type from both SS and CS fields is loamy sand (Table 1). 
Field rating of PCS. The SS and CS fields were divided into 5by-10 quadrants with 4 by $7 \mathrm{~m}^{2} /$ quadrant. Potato plants ('Snowden') were dug and the tubers were scored for common scab disease. Fifty tubers were randomly selected from each plot for disease evaluation. Disease lesions on potato tubers were scored as previously described (8), with slight modification: $0=$ no symptoms; $1=1$ to $10,2=11$ to 25 , and $3=26$ to $50 \%$ surface area with superficial or raised lesions; $4=>50 \%$ surface area with superficial or raised lesions or $<25 \%$ pitted lesion area; and $5=>50 \%$ surface area with superficial or raised lesions or $>25 \%$ pitted area. The disease severity index was calculated as $\Sigma$ (score $\times$ number of tubers with that score)/total number of potato tubers evaluated. Scab ratings were conducted for both SS and CS after harvest in 2007 and 2008.

Greenhouse assay of soil-suppressing scab diseases of radish and potato. Plant inoculation. Pathogen inoculum was prepared following the method described by Wanner (34) with slight modification. Streptomyces scabies strains 1019 from Michigan and 49173 from the American Type Culture Collection were cultured on yeast malt extract (YME; EMB Chemical Inc., Gibbstown, NJ) agar incubated in the dark at $28^{\circ} \mathrm{C}$ for 5 days or until spores were produced. A spawn bag (19 by 8 by 5 in.; Fungi Perfecti, LLC, Olympia, WA) was filled with $2,000 \mathrm{~cm}^{3}$ of vermiculite (medium size, premium grade; Sun Gro Horticulture Distribution Inc., Bellevue, WA) and $200 \mathrm{ml}$ of water per bag, and autoclaved for $1 \mathrm{~h}$ twice in $24 \mathrm{~h}$. Spore suspensions $\left(10^{7} \mathrm{CFU} / \mathrm{ml}\right)$, determined by enumerating colonies on YME plates of $S$. scabies, were prepared by adding $10 \mathrm{ml}$ of sterile distilled water to culture plates and scraping colonies using a sterile scalpel. A mixture (1:1 in volume, $10 \mathrm{ml}$ of each) of S. scabies isolates 1019 and 49173 was added to $180 \mathrm{ml}$ of $2 \times$ Say solution (8), which was then mixed into the sterile vermiculite in the spawn bags. The vermiculite inoculum bags were incubated at $28^{\circ} \mathrm{C}$ and mixed every other day by shaking. To determine the inoculum density, $1 \mathrm{~cm}^{3}$ of vermiculite with $S$. scabies was transferred into $9 \mathrm{ml}$ of sterile distilled water. Serial dilutions were prepared and plated $(100 \mu \mathrm{l})$ on YME agar. After 5 days of incubation in the dark at $28^{\circ} \mathrm{C}$ colonies of $S$. scabies were enumerated.

In a greenhouse, cut seed tubers of potato ('Atlantic') were placed in soil infested with $S$. scabies (see below) in 6-liter pots. Fertilizer $(\mathrm{N}: \mathrm{P}: \mathrm{K}$ ratio $=24: 8: 16$; Scotts Miracle Gro Products, Inc., Marysville, $\mathrm{OH}$ ) was applied once every other week after seedlings were $2.5 \mathrm{~cm}$ high. There were four replications (pots) for each treatment. Growth conditions in the greenhouse were $24^{\circ} \mathrm{C}$ with a 14-h photoperiod, supplemented by light at $200 \mu \mathrm{mol} \mathrm{m} \mathrm{m}^{-2} \mathrm{~s}^{-1}$ provided by cool white fluorescent lamps. Plants were watered with 100 to $200 \mathrm{ml} /$ pot every 2 to 3 days. Four months after planting, potato tubers were harvested and evaluated visually for scab symptoms with the method mentioned above.

Radish is another important host of Streptomyces spp. and is often used for pathogenicity tests because it has a shorter life cycle (34). Radish ('Cherry Belle') seed were planted $0.5 \mathrm{~cm}$ below the soil surface and grown in the greenhouse in 1-liter pots at the same conditions as described above for potato. After seedlings had germinated, plants were thinned to six plants per pot (evenly spaced) and watered with $100 \mathrm{ml} /$ pot daily. Radish plants were fertilized as with potato plants mentioned above 3 weeks after planting and harvested 6 weeks later. There were four replications (pots) for each treatment. Radish hypocotyls were scored on a scale of 0 to 5 , as described by Wanner (34).

Effect of soil mixtures on disease suppression of SS. Soil was randomly collected from five locations at the SS field and mixed together. Half of the SS was autoclaved twice (120 min for each) in $24 \mathrm{~h}$, and mixed with nonautoclaved SS at volume ratios of (SS/autoclaved SS) of 100:0, 80:20, 40:60, 20:80, and 0:100 for the first trial and 100:0, 75:25, 50:50, 25:75, and 0:100 for the second trial. S. scabies inoculum in vermiculite was mixed into the soil thoroughly and the final inoculum level in the soil was adjusted to $10^{6} \mathrm{CFU} / \mathrm{cm}^{3}$ of soil. There were four replications (pots) for each treatment. The trials with two sets of volume ratios were tested on both potato and radish.
Effect of heating temperature on disease suppression of SS. SS was sampled with the same method described above and placed in high-temperature resistant bags (10 liters/bag; Associate Bag, LLC, WI), and treated at $40,60,70,80$, and $90^{\circ} \mathrm{C}$ in a water bath for 30 min, starting when the center of the soil bag reached the expected temperature and measured with a metal temperature probe (NovaTech International Inc., TX). An additional bag was autoclaved $\left(121^{\circ} \mathrm{C}\right)$ for $30 \mathrm{~min}$. In a second trial, SS was sampled, bagged as before, and treated at $30,45,60,75$, and $90^{\circ} \mathrm{C}$ for $30 \mathrm{~min}$ in a water bath, and $121^{\circ} \mathrm{C}$ (autoclaving) for $30 \mathrm{~min}$. There were four replications (pots) for each treatment. For both trials, after the temperature treatment, the soil was mixed with $S$. scabies inoculum in vermiculite at the final concentration of $10^{6} \mathrm{CFU} / \mathrm{cm}^{3}$ of mixed soil. Nontreated and autoclaved soil without infestation was used as control. These two trials with different temperature sets were tested on both potato and radish.

Characterization of soil microbial communities in diseaseconducive and -suppressive soils. Microbial communities assayed by dilution plating method. Soil samples were collected from CS and SS fields. Bulk soil was collected in the area between plants. Sample volumes consisted of about 2 liters, around five trowels full taken from the top $15 \mathrm{~cm}$ soil, at five random locations. After being transported to the laboratory, the soil was mixed thoroughly in a plastic bag. Each soil sample $(10 \mathrm{~g})$ was suspended in $90 \mathrm{ml}$ of sterilized phosphate-buffered saline in 125-ml Erlenmeyer flasks and shaken for $20 \mathrm{~min}$ at $300 \mathrm{rpm}$. For rhizosphere soil sampling, potato roots were dug out and placed in a plastic bag. In the laboratory, the roots were hand shaken loosely, and soil attached to the roots surface was used.

Suspensions were serially diluted and $100 \mu \mathrm{l}$ of each soil dilution was spread onto three replicate plates of four different semiselective agar media. The media used and the target microbial communities were as follows: rose bengal agar (EMD Chemicals) with chloramphenicol $(0.1 \mathrm{~g} /$ liter $)$ for total fungi, 1/10-strength tryptic soy agar (TSA; EMD Chemicals) for total bacteria, S1 (31) for florescent pseudomonads, and Streptomyces-selective (STR) medium (4) for streptomycetes. TSA was also used to culture Bacillus spp. from soil dilutions heated to $80^{\circ} \mathrm{C}$ for $30 \mathrm{~min}$ before plating. All plates were incubated at room temperature $\left(22 \pm 1^{\circ} \mathrm{C}\right)$ and enumerated after 2 days (total bacteria, Bacillus, and fluorescent pseudomonads), 3 days (fungi), or 7 days (Streptomyces spp.).

Microbial communities assayed by terminal restriction fragment length polymorphism. Soil was collected as described above from both CS and SS fields and each mixed thoroughly. Half a gram of soil from each sample was used for total soil genomic DNA extraction, using the FastDNA Spin Kit for soil (MP Biomedicals, Solon, $\mathrm{OH})$ following the manufacturer's instruction. Polymerase chain reaction (PCR) was conducted with primer FAM-63F (5'-CAG GCC TAA CAC ATG CAA GTC-3') labeled with 6-carboxyfluorescein, and 1387R (5'-GGG CGG WGT GTA CAA GGC-3') (21), which are universal primers amplifying the $16 \mathrm{~S}$ rDNA gene of bacteria. Each PCR reaction had a total volume of $25 \mu$ l, containing $5 \mathrm{U}$ of Taq DNA polymerase, $5 \times$ Taq polymerase PCR buffer (Promega Corp., Madison, WI), $200 \mathrm{mM}$ dNTP mixture, $0.2 \mathrm{mM}$

Table 1. Physical and chemical properties of disease-conducive and -suppressive soils

\begin{tabular}{lcc}
\hline Soil character & $\begin{array}{c}\text { Disease-suppressive } \\
\text { soil }\end{array}$ & $\begin{array}{c}\text { Disease-conducive } \\
\text { soil }\end{array}$ \\
\hline Soil pH & 6.8 & 6.2 \\
$\mathrm{P}(\mathrm{ppm})$ & 378.0 & 389.0 \\
$\mathrm{~K}(\mathrm{ppm})$ & 252.0 & 146.0 \\
$\mathrm{Mg}(\mathrm{ppm})$ & 129.0 & 63.0 \\
$\mathrm{Ca}(\mathrm{ppm})$ & 720.0 & 383.0 \\
$\mathrm{CEC}(\mathrm{meq} / 100 \mathrm{~g})$ & 5.3 & 4.0 \\
Exchangeable K $(\%)$ & 12.1 & 13.3 \\
Exchangeable $\mathrm{Mg}(\%)$ & 20.2 & 18.7 \\
Exchangeable Ca $(\%)$ & 67.7 & 68.0 \\
Soil type & Loamy sand & Loamy sand \\
\hline
\end{tabular}


each primer, and $1 \mu \mathrm{l}$ ( 2 to $25 \mathrm{ng} / \mu \mathrm{l})$ of template DNA. Amplifications were performed on a thermocycler with an initial denaturation step of $5 \mathrm{~min}$ at $94^{\circ} \mathrm{C}$; followed by 36 cycles of $40 \mathrm{~s}$ at $94^{\circ} \mathrm{C}$, $40 \mathrm{~s}$ at $58^{\circ} \mathrm{C}$, and $1.5 \mathrm{~min}$ at $72^{\circ} \mathrm{C}$; and a final extension of $7 \mathrm{~min}$ at $72^{\circ} \mathrm{C}$. After confirmation by electrophoresis on $1.2 \%$ (wt/vol) agarose gel, PCR products were purified using the PCR Purification Kit (Denville Scientific Inc., Metuchen, NJ), and digested with $R s a \mathrm{I}$ and MspI enzymes (New England Biolabs Inc., Ipswich, MA) following the manufacturer's instructions and purified by ethanol precipitation. Restriction digests were separated by capillary electrophoresis using an ABI 3130 xl DNA analyzer and data analyzed using GeneScan 3.7 software (Applied Biosystems, Carlsbad, CA) to determine digested fragment sizes.

Frequency of antagonistic bacteria against $\mathrm{S}$. scabies. Isolates of Bacillus spp., fluorescent Pseudomonas spp., Streptomyces spp., and total bacteria, isolated from dilution plating (as described above), were tested for antagonism against $S$. scabies in vitro using a co-plate assay (38). Spore suspension of S. scabies strain 1019
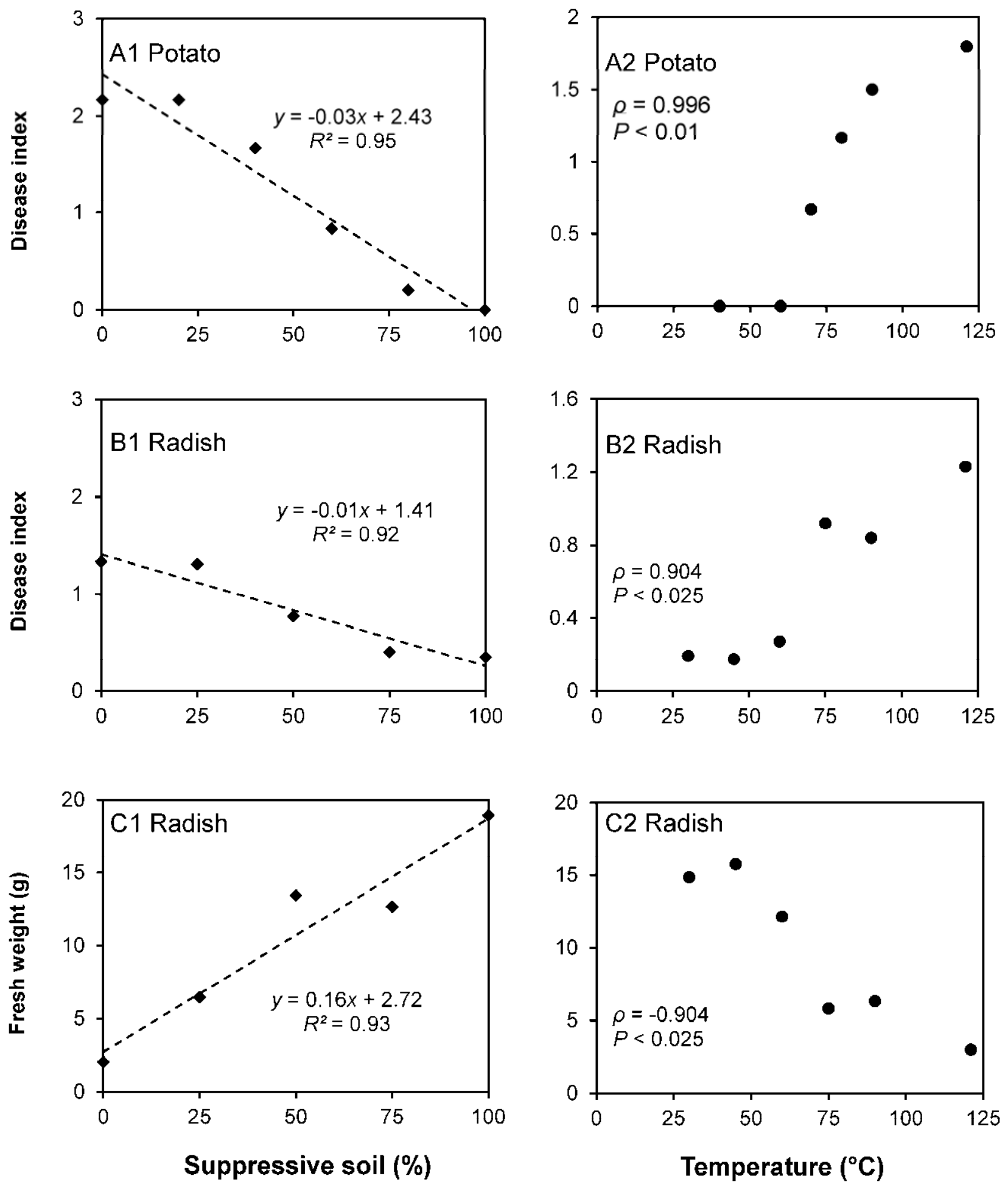

Fig. 1. Characterization of disease-suppressive (SS) soil in potato and radish in the greenhouse. SS was either $\mathbf{A} 1$, B1, and $\mathbf{C 1}$, mixed with autoclaved SS at various portions; or A2, B2, and C2, treated with various temperatures for $30 \mathrm{~min}$, followed by infesting the soil with Streptomyces scabies at final concentration of $10^{6}$ CFU/ $\mathrm{cm}^{3}$ of soil. Either potato (A1 and A2) or radish (B1 and B2) was seeded in the treated soils in a pot. Disease was rated and potato common index was calculated according to published procedures $(8,34)$. Weight of fresh radish roots was measured in both trials $(\mathrm{C} 1$ and $\mathrm{C} 2)$. 
was prepared as described above. Antibiosis assays were done as follows: spore suspension $(100 \mu \mathrm{l})$ of strain 1019 with the concentration of $10^{5} \mathrm{CFU} / \mathrm{ml}$ (determined by dilution plating) was spread on a YME agar plate and allowed to air dry in a laminar flow hood. Different isolates growing on the selective media (as described above) were selected to culture with $S$. scabies strain 1019. Ten isolates were tested on each plate and replicated three times. Plates were incubated at $28^{\circ} \mathrm{C}$ for more than 3 days and the number of antagonists were recorded. This trial was conducted over 3 years, from 2007 to 2010.

Frequency of pathogenic Streptomyces spp. Streptomyces spp. from SS and CS were obtained from isolation by dilution plating on STR media (as described above). From each soil (including bulk and rhizosphere soil), 150 isolates were randomly selected. All these isolates were purified and grown on YME agar for 7 to 10 days. Potato tubers were sliced and cut into disks $0.5 \mathrm{~cm}$ in height and $2.0 \mathrm{~cm}$ in diameter. The disks were placed on moistened filter paper in petri plates. Mycelial plugs $(5 \mathrm{~mm}$ ) of Streptomyces spp. isolates were placed in the center of the tuber disk (18). Noninoculated YME agar plugs were used as controls. Necrotic lesions on potato disks around the Streptomyces inoculum were observed and measured at room temperature after 3 to 5 days in the dark.

Statistical analysis. Data were analyzed using SAS software (version 9; SAS Inc., Cary, NC). Procedure GLM was used for analysis of variance and Fisher's least significance difference. Multiple comparisons were performed for mean separation. Procedure REG was used for linear regression. Procedure Spearman rank correlation was used to analyze disease and plant growth response to temperatures. Terminal restriction fragment length polymorphism (T-RFLP) Cluster analysis was performed using the Rstatistical package (v. 2.10; Revolution Analytics, Palo Alto, CA).

\section{Results}

Field rating of PCS disease severity. Scab ratings of the SS field was $1.43 \pm 0.45$ and $1.55 \pm 0.56$ in 2007 and 2008, respectively, which were significantly lower $(P<0.05)$ than scab ratings from CS field, which ranged from $2.6 \pm 0.62$ to $2.6 \pm 0.54$ in 2007 and 2008, respectively.

Greenhouse assays of soil suppressing scab diseases in radish and potato. Effect of soil mixtures of suppressive and autoclaved soils on PCS disease. Disease suppressiveness was measured by assessing the disease severity in both potato and radish planted in a soil mixture of untreated natural SS and autoclaved SS. As the percentage of the SS increased, the disease severity decreased in both potato and radish (Fig. 1A1 and B1). No common scab symptoms were observed in potato planted in $100 \%$ SS (Fig. 1A1). This relationship fit a simple linear regression model with $R^{2}=0.95(P$ $<0.05$; Fig. 1A1) and $R^{2}=0.92(P<0.05$; Fig. 1B1). Plant fresh weight was positively correlated $\left(R^{2}=0.93, P<0.05\right)$ with the percentage of SS: higher radish weights were obtained from higher percentages of SS, and vice versa (Fig. 1C1).
Effect of soil temperature treatments on PCS disease suppression. Temperature treatment impacted the disease suppression in both potato and radish. The disease severity showed a positive relationship with the temperature used for soil treatment. Disease suppression was significantly reduced by temperatures above $60^{\circ} \mathrm{C}$ (Fig. 1A2 and B2). The values of Spearman's rho $(\rho)$ were 0.996 $(P<0.01)$ for potato and $0.904(P<0.025)$ for radish. Plant fresh weight was negatively correlated with temperature treatments: higher radish weights were obtained from soil treated with lower temperatures, and vice versa (Fig. 1C2; $\rho=-0.904,0.01<P<$ 0.025).

Characterization of soil microbial communities from disease conducive and suppressive soils. Microbial communities assayed by dilution plating. Analysis from eight sampling times gave mixed results (Table 2). There were no clear trends in microbial populations among CS and SS. In most trials, SS had higher population numbers of total fungi, total bacteria, streptomycetes, fluorescent pseudomonads, and bacilli in most soil samples tested. However, the majority of these differences were not statistically significant $(P<0.05)$ within the same sampling dates (Table 2$)$.

Microbial communities assayed by T-RFLP. Analysis of T-RFLP fragments digested with $R s a \mathrm{I}$ and $M s p \mathrm{I}$ resulted in two major clusters for SS and CS (Fig. 2), indicating that two distinct microbial communities inhabited these two types of soils. The variation among samples from the same field was low.

Frequency of antagonistic bacteria against S. scabies. In total, 5,285 single bacterial colonies were obtained from semiselective media plates and included isolates from total bacteria, fluorescent pseudomonads, streptomycetes, and bacilli. All together, 961 (18\%) isolates that included 573 and 388 isolates from SS and DS, respectively, exhibited antagonism against $S$. scabies (Fig. 3). In all four groups sampled from 2007 to 2010, the frequency of antagonistic bacteria in SS $(0.27,0.19,0.49$, and 0.24 from bacilli, total bacteria, pseudomonads, and streptomycetes, respectively) was higher than CS $(0.23,0.13,0.30$, and 0.0 .18 from bacilli, total bacteria, pseudomonads, and streptomycetes, respectively) but only differences in pseudomonads and streptomycetes were significant $(P<0.05$; Fig. 3$)$.

Frequency of pathogenic Streptomyces spp. The frequency of pathogenic streptomycetes was higher in the rhizosphere than in the bulk soil. Rhizosphere CS had a significantly higher frequency of pathogenic streptomycetes than SS. Moreover no difference in the frequency of pathogenic Streptomyces spp. from bulk soil was found (Fig. 4).

\section{Discussion}

We have demonstrated that soil suppression of PCS corresponds with differences in microbial community structure. The disease suppression is transferable from soil to soil, and can be reduced or eliminated by high-temperature treatments. Continuous crop monoculture could be the driving force for the development of the

Table 2. Microbial populations in disease-suppressive (SS) and -conducive (CS) soils detected by dilution plating on semiselective media

\begin{tabular}{|c|c|c|c|c|c|c|c|c|c|c|}
\hline \multirow[b]{2}{*}{ Microorganism } & \multirow[b]{2}{*}{ Soil } & \multicolumn{8}{|c|}{ Date of soil sampling ${ }^{z}$} & \multirow[b]{2}{*}{ Average } \\
\hline & & $\begin{array}{l}17 \text { January } \\
2006\end{array}$ & $\begin{array}{l}10 \text { April } \\
2007\end{array}$ & $\begin{array}{c}10 \text { July } \\
2007\end{array}$ & $\begin{array}{l}22 \text { April } \\
2008\end{array}$ & $\begin{array}{l}6 \text { August } \\
2008\end{array}$ & $\begin{array}{c}4 \text { December } \\
2008\end{array}$ & $\begin{array}{c}3 \text { July } \\
2009\end{array}$ & $\begin{array}{c}13 \text { May } \\
2010\end{array}$ & \\
\hline \multirow[t]{2}{*}{ Total fungi } & SS & 4.87 & 5.09 & $6.29 \mathrm{~b}$ & 5.13 & $4.70 \mathrm{~b}$ & 4.68 & 5.11 & $5.59 \mathrm{a}$ & 5.18 \\
\hline & CS & 4.82 & 5.22 & $6.63 \mathrm{a}$ & 5.03 & $5.04 \mathrm{a}$ & 4.65 & 5.26 & $5.24 \mathrm{~b}$ & 5.24 \\
\hline \multirow[t]{2}{*}{ Total bacteria } & SS & 6.95 & $7.5 \mathrm{~b}$ & 7.70 & 5.57 & 5.60 & 5.54 & 6.79 & $6.84 \mathrm{a}$ & 6.56 \\
\hline & $\mathrm{CS}$ & 6.99 & $7.84 \mathrm{a}$ & 7.68 & 5.44 & 5.58 & 5.47 & 6.86 & $6.45 \mathrm{~b}$ & 6.54 \\
\hline \multirow[t]{2}{*}{ Streptomycetes } & SS & 5.50 & $6.08 \mathrm{~b}$ & 6.99 & 5.42 & $5.19 \mathrm{a}$ & $5.40 \mathrm{a}$ & 5.45 & 5.76 & 5.72 \\
\hline & $\mathrm{CS}$ & 5.24 & $6.56 \mathrm{a}$ & 7.03 & 5.19 & $4.73 \mathrm{~b}$ & $5.27 \mathrm{~b}$ & 5.49 & 5.65 & 5.65 \\
\hline \multirow[t]{2}{*}{ Fluorescent pseudomonads } & SS & - & 5.52 & 6.46 & 4.66 & 4.52 & $4.84 \mathrm{a}$ & 4.61 & 5.43 & 5.15 \\
\hline & $\mathrm{CS}$ & - & 5.62 & 6.58 & 3.78 & 4.37 & $4.10 \mathrm{~b}$ & 4.07 & 5.26 & 4.83 \\
\hline \multirow[t]{2}{*}{ Bacilli } & SS & - & $5.49 \mathrm{a}$ & 6.88 & 5.28 & $5.28 \mathrm{~b}$ & $5.29 \mathrm{~b}$ & 5.46 & 5.76 & 5.63 \\
\hline & $\mathrm{CS}$ & - & $5.14 \mathrm{~b}$ & 6.71 & 5.34 & $5.48 \mathrm{a}$ & $5.41 \mathrm{a}$ & 5.47 & 5.74 & 5.61 \\
\hline
\end{tabular}

${ }^{\mathrm{z}}$ Microbial population was expressed as logarithmic transformation of CFU per gram of soil. Multiple comparisons were performed using Fisher's least square difference test at significance level $\alpha=0.05$. Values followed by same letters have no significant differences in the same column of the table; - indicates data were not available. 
observed disease suppression, as demonstrated previously with common scab and other disease systems $(17,28,36)$.

The disease suppression was affected by temperatures higher than $60^{\circ} \mathrm{C}$. The corresponding organisms for suppressiveness could be elucidated based on the maximum temperatures they can tolerate. In this study, the suppression does not, or decreases little below $60^{\circ} \mathrm{C}$, indicating that the contribution due unicellular bacteria, such as pseudomonads, may be limited. Loss of suppressiveness around $80^{\circ} \mathrm{C}$ supports the role of streptomycetes and that, at higher temperatures, support spore-forming organisms such as bacilli or other fungi may be important $(22,36,38)$.

After narrowing the scope of organisms of interest responsible for the suppressiveness, further investigation was conducted based on the microbial community comparison between SS and CS. The successive planting of potato may have enhanced the soil microbial community and resulted in the accumulation of host-specific beneficial organisms, including antagonists against plant pathogens (2). In this study, the frequency of antagonistic bacteria from SS was significantly higher than CS, particularity in the case of streptomycetes. Streptomyces spp. produce a range of antibiotics (20) that may contribute to disease suppression. The frequency of pathogenic Streptomyces spp. in the SS in this study was less than that in the CS but total streptomycetes were higher in the SS. Nonpathogenic streptomycetes, such as $S$. diastatochromogenes and $S$. albogriseolus, can produce antibiotic-like compounds active against $S$. scabies, and are considered to be important biological components of disease suppression $(3,17)$. Greater numbers of nonpathogenic Streptomyces spp. are associated with less severe common scab, suggesting that an interaction between host plant and Streptomyces microbial communities affects disease severity of

\section{Msp I}

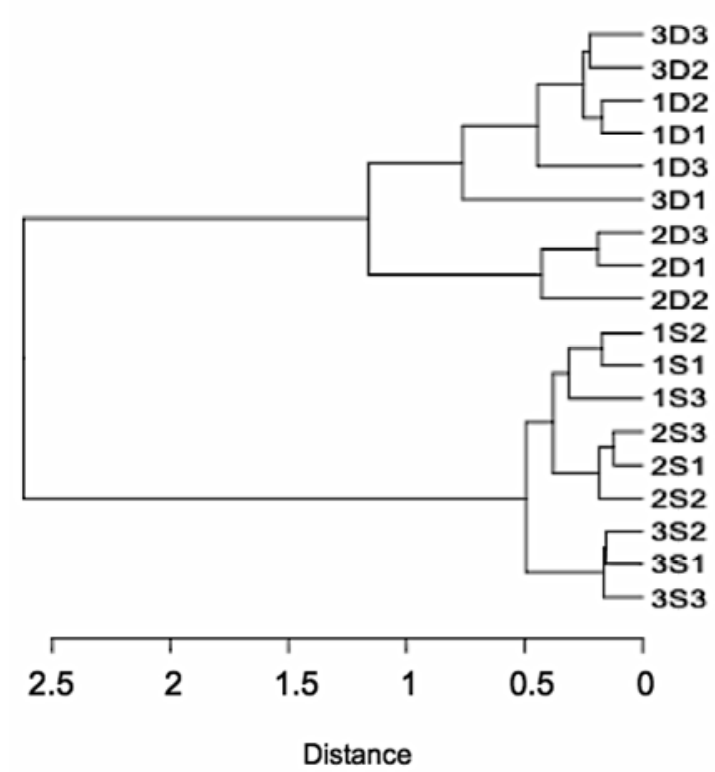

Rsa I

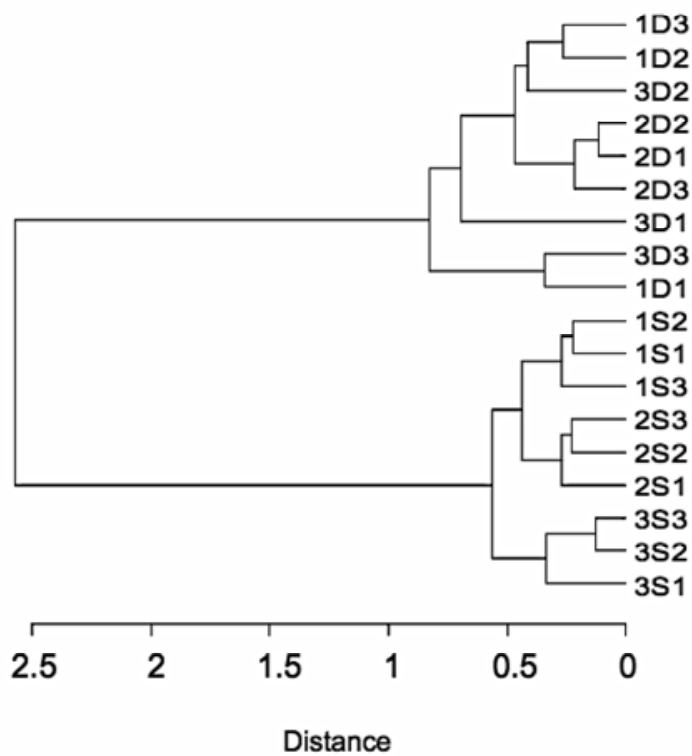

Fig. 2. Dendrograms of terminal restriction length polymorphs. Soil samples are designated with number-letter-number format, where letter $S$ means disease-suppressive soil and D means disease-conducive soil. The number before the letter indicates soil samples and the number after the letter indicates replications of DNA extraction. DNA was digested with either Mspl or Rsal restriction enzyme.

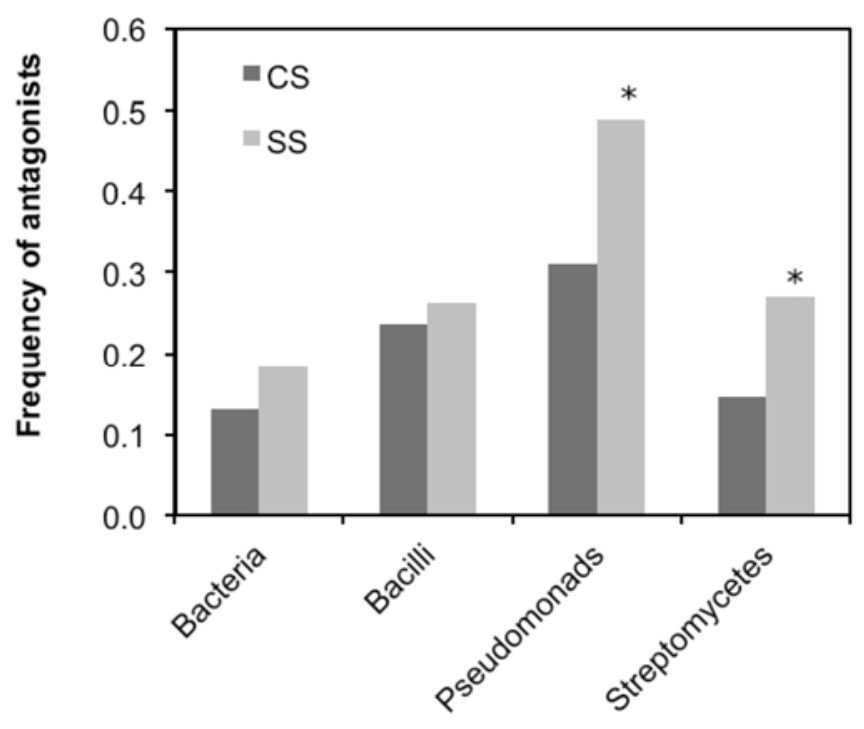

Fig. 3. Frequency of antagonists from bulk soil (result was derived from combined data sampled on 10 April 2007, 4 November 2008, 3 July 2009, and 13 May 2010 in both disease-suppressive (SS) and -conducive (CS) soils. An asterisk $\left({ }^{*}\right)$ indicates significant differences between SS and CS at $\alpha=0.05$

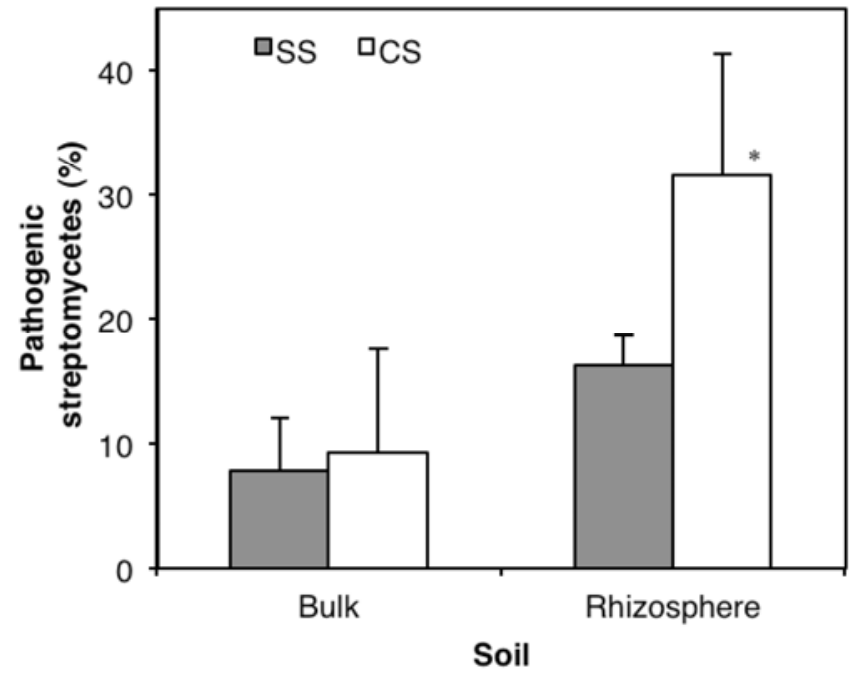

Fig. 4. Frequency of pathogenic Streptomyces strains isolated from bulk and rhizosphere soils in both disease-suppressive (SS) and -conducive (CS) soils. Bars over the values are standard deviation and an asterisk $\left({ }^{*}\right)$ indicates significant differences between SS and CS at $\alpha=0.05$. Result was derived from combined data sampled on 10 July 2007 and 13 May 10. 
PCS $(3,30)$. Disease-causing strains of $S$. scabies can be controlled by nonpathogenic Streptomyces strains when the pathogenic and nonpathogenic isolates coexist at a certain ratio $(9,27)$. This inhibition is especially important if nonpathogenic streptomycetes compete for nutrition and colonization, and can produce inhibitory compounds toward pathogens $(25,30)$.

According to the results of different soil temperature treatments, other possible organisms responsible for the suppressive mechanism are Bacillus spp., which have been proven as pathogen antagonists in nature and can be used as biological control agents, such as Bacillus subtilis (11) and B. amyloliquefaciens (1). In this study, the population of bacilli in SS was larger than that in CS, without being significantly different. This is in agreement with results of pyrosequencing analysis in our companion study (29). However, if the relative abundance of bacilli did not play an important role, it is possible that the species or population composition of this group is different between the two soils.

There may be other candidate microbes that could be involved in disease suppressiveness. Results from pyrosequencing analysis showed that Lysobacter spp. were significantly higher in diseasesuppressive soil than in the CS (29). Several isolates within this genus display potential biocontrol activities and inhibit diseasecausing bacteria, fungi, and oomycetes $(6,26)$. The role of $L y$ sobacter spp. in this suppressive soil remains unclear and needs further study.

Based on our study, the disease suppression was due to a group of microorganisms, including bacilli, florescent pseudomonads, and nonpathogenic streptomycetes. Results from culture-based and molecular studies, taken together, suggest distinct communities made up of different functional groups capable of PCS diseases suppression. More groups of microorganism have been identified using alternative methods (29).

\section{Acknowledgments}

This project was partially supported by the Michigan Potato Industry Commission and Michigan State University Project GREEEN. We thank Dr. Ray Hammerschmidt for having done preliminary work related to this project and providing a critical review of this manuscript, Dr. S. Durairaj for assisting in greenhouse disease evaluation, X. Lu for laboratory assistance, and D. Berry and J. Coombs for technical support in the field.

\section{Literature Cited}

1. Arguelles-Arias, A., Ongena, M., Halimi, B., Lara, Y., Brans, A., Joris, B., and Fickers, P. 2009. Bacillus amyloliquefaciens GA1 as a source of potent antibiotics and other secondary metabolites for biocontrol of plant pathogens. Microb. Cell Fact 8:63.

2. Borneman, J., and Becker, J. O. 2007. Identifying microorganisms involved in specific pathogen suppression in soil. Annu. Rev. Phytopathol. 45:153172.

3. Bowers, J. H., Kinkel, L. L., and Jones, R. K. 1996. Influence of diseasesuppressive strains of Streptomyces on the native Streptomyces community in soil as determined by the analysis of cellular fatty acids. Can. J. Microbiol. 42:11.

4. Conn, K. L., Leci, E., Kritzman, G., and Lazarovits, G. 1998. A quantitative method for determining soil populations of Streptomyces and differentiating potential potato scab-inducing strains. Plant Dis. 82:631-638.

5. Davis, J. R., Mcmaster, G. M., Callihan, R. H., Nissley, F. H., and Pavek, J. J. 1976. Influence of soil moisture and fungicide treatments on common scab and mineral content of potatoes. Phytopathology 66:228-230.

6. Folman, L. B., Postma, J., and van Veen, J. A. 2003. Characterisation of Lysobacter enzymogenes (Chistensen and Cook 1978) strain 3.1T8, a powerful antagonist of fungal diseases of cucumber. Microbiol. Res. 158:107-115

7. Haas, D, and Defago, Genevieve. 2005. Biological control of soil-borne pathogens by fluorescent pseudomonads. Nat. Rev. Microbiol. 3:307-320.

8. Hao, J. J., Meng, Q. X., Yin, J. F., and Kirk, W. W. 2009. Characterization of a new Streptomyces strain, DS3024, that causes potato common scab. Plant Dis. 93:1329-1334.

9. Hiltunen, L. H., Ojanpera, T., Kortemaa, H., Richter, E., Lehtonen, M. J., and Valkonen, J. P. T. 2009. Interactions and biocontrol of pathogenic Streptomyces strains co-occurring in potato scab lesions. J. Appl. Microbiol. 106:199-212.

10. Kao, W., and Ko, W. H. 1986. Suppression of Pythium splendens in a Hawaiian soil by calcium and microorganisms. Phytopathology 76:215-220.

11. Kim, P. I., Ryu, J., Kim, Y. H., and Chl, Y. T. 2010. Production of biosurfactant lipopeptides iturin A, fengycin, and surfactin A from Bacillus subtilis CMB32 for control of Colletotrichum gloeosporioides. J Microbiol.
Biotechnol. 20:138-145.

12. Larkin, R. P. 2008. Relative effects of biological amendments and crop rotations on soil microbial communities and soilborne diseases of potato Soil Biol. Biochem. 40:1341-1351.

13. Larkin, R. P., Hopkins, D. L., and Martin, F. N. 1996. Suppression of Fusarium wilt of watermelon by nonpathogenic Fusarium oxysporum and other microorganisms recovered from a disease-suppressive soil. Phytopathology 86:812-819.

14. Liu, D. Q., Anderson, N. A., and Kinkel, L. L. 1995. Biological control of potato scab in the field with antagonistic Streptomyces scabies. Phytopathology 85:827-831.

15. Liu, W. T., Marsh, T. L., Cheng, H., and Forney, L. J. 1997. Characterization of microbial diversity by determining terminal restriction fragment length polymorphisms of genes encoding 16S rRNA. Appl. Environ. Microbiol. 63:4516-4522.

16. Lorang, J. M., Anderson, N. A., Lauer, F. I., and Wildung, D. K. 1989 Disease decline in a Minnesota potato scab plot. Am. J. Potato Res. 66:531.

17. Lorang, J. M., Liu, D., Anderson, N. A., and Schottel, J. L. 1995. Identification of potato scab inducing and suppressive species of Streptomyces. Phytopathology 85:261-268.

18. Loria, R., Bukhalid, R. A., Creath, R. A., Leiner, R. H., Olivier, M., and Steffens, J. C. 1995. Differential production of thaxtomins by pathogenic Streptomyces species in vitro. Phytopathology 85:537-541.

19. Loria, R., Bukhalid, R. A., Fry, B. A., and King, R. R. 1997. Plant pathogenicity in the genus Streptomyces. Plant Dis. 81:836-846.

20. Loria, R., Kers, J., and Joshi, M. 2006. Evolution of plant pathogenicity in Streptomyces. Annu. Rev. Phytopathol. 44:469-487.

21. Marchesi, J. R., Sato, T., Weightman, A. J., Martin, T. A., Fry, J. C., Hiom, S. J., Dymock, D., and Wade, W. G. 1998. Design and evaluation of useful bacterium-specific PCR primers that amplify genes coding for bacterial $16 \mathrm{~S}$ rRNA. Appl. Environ. Microbiol. 64:795-799.

22. Mendes, R., Kruijt, M., de Bruijn, I., Dekkers, E., van der Voort, M., Schneider, J. H. M., Piceno, Y. M., DeSantis, T. Z., Andersen, G. L., Bakker P. A. H. M., and Raaijmakers, J. M. 2011. Deciphering the rhizosphere microbiome for disease-suppressive bacteria. Scienceexpress 5 May. (science.1203980).

23. Meng, Q., Yin, J., Hammerschmidt, R., Kirk, W., and Hao, J. 2009. Characterization of a naturally occurred suppressive soil to potato common scab in Michigan. (Abstr.) Phytopathology 99:S84.

24. Menzies, J. D. 1959. Occurrence and transfer of a biological factor in soil that suppresses potato scab. Phytopathology 49:648-652.

25. Neeno-Eckwall, E. C., Kinkel, L. L., and Schottel, J. L. 2001. Competition and antibiosis in the biological control of potato scab. Can. J. Microbiol. 47:332-340.

26. Park, J. H., Kim, R., Aslam, Z., Jeon, C. O., and Chung, Y. R. 2008. Lysobacter capsici sp. nov., with antimicrobial activity, isolated from the rhizosphere of pepper, and emended description of the genus Lysobacter. Int. J. Syst. Evol. Microbiol. 58:387-392.

27. Postma, J., Scheper, R. W. A., and Schilder, M. T. 2010. Effect of successive cauliflower plantings and Rhizoctonia solani AG 2-1 inoculations on disease suppressiveness of a suppressive and a conducive soil. Soil Biol. Biochem. 42:804-812.

28. Postma, J., Schilder, M., Bloem, J., van Leeuwen-Haagsma, W. 2008. Soil suppressiveness and functional diversity of the soil microflora in organic farming systems. Soil Biol. Biochem. 40:2394-2406.

29. Rosenzweig, N., Tiedje, J. M., Quensen, J. F., III, Meng, Q., and Hao, J. J. 2012. Microbial communities associated with potato common scab-suppressive soil determined by pyrosequencing analyses. Plant Dis. 96:718-725.

30. Schottel, J. L., Shimizu, K., and Kinkel, L. L. 2001. Relationships of in vitro pathogen inhibition and soil colonization to potato scab biocontrol by antagonistic Streptomyces spp. Biol. Control 20:102-112.

31. Tarnawski, S., Hamelin, J., Locatelli, L., Aragno, M., and Fromin, N. 2003. Examination of Gould's modified S1 (mS1) selective medium and Angle's non-selective medium for describing the diversity of Pseudomonas spp. in soil and root environments. FEMS Microbiol. Ecol. 45:97-104.

32. Tsao, P. H. 1970. Selective media for isolation of pathogenic fungi. Annu. Rev. Phytopathol. 8:157-186.

33. van Elsas, J. D., Speksnijder, A., and van Overbeek, L. S. 2008. A procedure for the metagenomics exploration of disease-suppressive soils. J. Microbiol Methods 75:515-522.

34. Wanner, L. A. 2004. Field isolates of Streptomyces differ in pathogenicity and virulence on radish. Plant Dis. 88:785-796.

35. Wanner, L. A., and Haynes, K. G. 2009. Aggressiveness of Streptomyces on four potato cultivars and implications for common scab resistance breeding. Am. J. Potato Res. 86:335-346.

36. Weller, D. M., Raaijmakers, J. M., Gardener, B. B. M., and Thomashow, L. S. 2002. Microbial populations responsible for specific soil suppressiveness to plant pathogens. Annu. Rev. Phytopathol. 40:309-347.

37. Wiggins, B. E., and Kinkel, L. L. 2005. Green manures and crop sequences influence potato diseases and pathogen inhibitory activity of indigenous streptomycetes. Phytopathology 95:178-185.

38. Yoshida, S., Hiradate, S., Tsukamoto, T., Hatakeda, K., and Shirata, A. 2001. Antimicrobial activity of culture filtrate of Bacillus amyloliquefaciens RC-2 isolated from mulberry leaves. Phytopathology 91:181-187. 